\title{
Vaurauden resilienssi koronakriisissä
}

\author{
PAULI HUOTARI
}

Koronapandemiaa on verrattu taloudellisena kriisinä useisiin historian suuriin kriiseihin pandemioista pörssiromahduksiin. Koronapandemia on kuitenkin kokonaisuutena varsin uniikki historiallinen tapahtuma, ja analogiat ovat usein enemmän tai vähemmän ontuvia. Tässä tekstissä tarkastelen kriisin muutamaa erityispiirrettä: Koronakriisissä työttömyys ampaisi valtavaan nousuun heti pandemian alussa ja maailmatalous kutistui vuonna 2020 yli kolme prosenttia. Samaan aikaan sekä miljardöörien määrä että omaisuus ovat kasvaneet ennätyslukemiin. Myös osakekurssit ovat kaikkien aikojen huippulukemissa. Mistä näissä ristiriitaisen tuntuisissa kehityskuluissa on kyse?

Taloudellisesti vaikeilla ajoilla on sosiaalisesti suurin vaikutus haavoittuvimmassa asemassa oleviin ihmisiin. Esimerkkinä voidaan mainita Suomen 1990-luvun lama, joka keskitti sosiaalisia ongelmia, lisäsi syrjäytymistä, aiheutti pitkittynyttä työttömyyttä ja monia muita yhteiskunnallisia ongelmia (ks. esim. Kiander 2001, 77-85). Samaan aikaan talouskriisit usein hidastavat taloudellisen eriarvoisuuden kasvua ainakin hetkellisesti, sillä rahamäärällisesti suurimmat tappiot kohdistuvat omistavaan luokkaan. Vaikka omistavan luokan elinehdot eivät ole uhattuna prekaarissa asemassa olevien työntekijöiden tavoin, sen omistaman omaisuuden arvo tyypillisesti laskee kriiseissä eniten.

Koronakriisin pidempiaikaisista taloudellisista vaikutuksista on toistaiseksi liian varhaista vetää pitkälle meneviä johtopäätöksiä. Meneillään olevassa kriisissä näyttää kuitenkin olevan puolia, jotka mahdollisesti erottavat sen aikaisemmista talouden kriiseistä. Osittain tämä johtuu siitä, että shokki on tullut markkinoiden ulkopuolelta ja seurauksena on ollut esimerkiksi kokonaisia kansantalouksien sulkuja. Koronakriisissä huipputuloisten omaisuus on jatkanut kasvuaan jo kriisin aikana ja rahoitusvarallisuuden arvo on palautunut poikkeuksellisen nopeasti. Kutsun tätä ilmiötä vaurauden resilienssiksi, eli selviytymiskyvykkyydeksi. Nähdäkseni vaurauden resilienssi liittyy yhtäältä tiettyyn historiallis-institutionaaliseen hetkeen maailmantaloudessa, jota määrittää markkinoiden voimakas fasilitointi, ei niiden aktiivinen ohjaus. Toisaalta resilienssiin vaikuttavat poliittisen toimijuuden jakautuminen globaalissa poliittisessa taloudessa sekä kapitalismin eri muodot eri maissa.

Tässä puheenvuorossa tarkastelen sitä, miten koronakriisi on vaikuttanut suuriin omaisuuseriin ja suuriin tuloihin, ja minkälaisia mahdollisia selitysmalleja alustaville empiirisille havainnoille voi- 
daan esittää. Otan tarkasteluuni esimerkkitapauksina osakemarkkinoiden kehityksen ja superrikkaiden omaisuuden koronapandemian aikana. Esimerkkitapauksista on uutisoitu koronakriisin aikana, mutta resilienssin mekanismien tarkastelu on julkisuudessa jäänyt vähemmälle. Tekstissä esitettyjen huomioiden on tarkoitus toimia alustuksena vaurauden resilienssiin pureutuvalle tutkimukselle, jonka toteuttaminen on mielekästä vasta, kun koronapandemian pidemmän aikavälin taloudelliset vaikutukset ovat paremmin tiedossa. Ilmiön ymmärtäminen vaatii myös lisää historiallista ja institutionaalista kontekstointia.

Datan saatavuuden takia puheenvuorossa ylikorostuu Yhdysvaltojen tilanne. Yhdysvallat on myös vaurauden resilienssin tarkastelun kannalta kiinnostava tapaus vaurauden voimakkaan keskittymisen takia. Edellisistä huomioista huolimatta monet käsitellyistä ilmiöistä ovat yleisiä globaalissa poliittisessa taloudessa, vaikka ne vaihtelevatkin voimakkuudeltaan eri maissa.

\section{Taloudellisen epätasa-arvon yleinen kehitys ja kriisien tulonjaolliset vaikutukset}

Teollisella aikakaudella voimakkain taloudellisen epätasa-arvon kasvu on suurimmaksi osaksi tapahtunut valtioiden välillä. Aasian suurten talouksien, kuten Kiinan ja Intian, nousu on kuitenkin tasoittanut globaalia eriarvoistumiskehitystä viimeisten vuosikymmenien aikana. Polarisaatio kaikkein rikkaimpien ja köyhimpien maiden välillä on silti jatkunut. Valtioiden välisten keskimääräisten erojen laskiessa valtioiden sisäinen eriarvoisuus on monin paikoin lähtenyt nousuun. Länsimaissa taloudellinen eriarvoistumiskehitys on kiihtynyt nopeasti 1970-luvulta lähtien (Piketty 2014), esimerkiksi suurimmassa osassa OECDmaista tuloerot ovat kasvaneet 1980-luvulta lähtien (Keeley 2015), ja varallisuuden keskittyminen on kaksinkertaisella tasolla tuloeroihin nähden (Balestra \& Tonkin 2018). Yhdysvallat on monella mittarilla teollisuusmaiden eriarvoistumiskehityksen ehdotonta kärkikastia (Stiglitz 2013).

1900- ja 2000-lukujen aikana suuret yhteiskunnalliset kriisit ovat usein supistaneet tulo- ja va- rallisuuseroja joko hetkellisesti tai pidemmäksi aikaa. Pidemmän aikavälin tuloerojen kaventuminen on ollut aktiivisen sääntely- ja verotuspolitiikan seurausta kuten Yhdysvalloissa 1930-luvun suuren laman jälkeen (Saez 2013). Maailmansotia lukuun ottamatta taloudellisen epätasa-arvon kasvu on kuitenkin ollut lähes universaali ilmiö, vaikka erityisesti toisen maailmansodan ja 1970-luvun välisenä aikana epätasa-arvon kasvu olikin erityisesti länsimaissa hitaampaa.

Máximo Camacho ja Gonzalo Palmieri (2018) ovat selvittäneet taantumien yleistä vaikutusta epätasa-arvon kasvuun. Heidän tarkastelunsa kattaa 43 maata eri mantereilta ja valtaosan maailman bruttokansantuotteesta. Tutkimuksen perusteella eri maiden ja erilaisten talouskriisien välillä on merkittäviä eroja. Esimerkiksi pankkikriiseillä on voimakas negatiivinen vaikutus rikkaimpien tulo-osuuksiin, mikä puolestaan hillitsee taloudellista epätasa-arvokehitystä. Camachon ja Palmierin yleinen havainto on, että taantumilla on suurimpaan osaan maista lievä negatiivinen vaikutus. Kuitenkin vuosien 1960 ja 2016 välillä taloudellisen epätasa-arvon kasvu on liittynyt talouden yleiseen kehitykseen ja talouden kriiseillä ei ole ollut tähän isossa kuvassa merkittävää vaikutusta. Camachon ja Palmierin hyödyntämän Gini-indeksin suhteen on hyvä huomioida, että se ottaa huonosti huomioon erilaiset taloudellisen epätasa-arvon kokoonpanot. Erityisesti viime vuosikymmeninä kaikkein suurituloisimpien omaisuuden tai tulojen kasvu ei välttämättä ole merkittävästi vaikuttanut ginikertoimen arvoon. Esimerkiksi Yhdysvalloissa ja Suomessa rikkaimman prosentin osuudella kaikista tuloista on huomattava vaikutus epätasa-arvon kehitykseen, mittakaavaeroista huolimatta (Saez 2016, 4; Riihelä \& Tuomala 2020).

Suomessa yleinen taloudellisen epätasa-arvon kehityssuunta on kulkenut hieman jäljessä Yhdysvaltoihin ja suurimpaan osaan Euroopasta verrattuna. Marja Riihelä ja Matti Tuomala (2020) jakavat tulonjaollisen kehityksen kahteen aikakauteen: hyvinvointivaltion rakennusaikaan 1966-1990 ja globaalin kilpailuvaltion aikaan 1990-2017. Näistä jälkimmäisen aikana käytettävissä olevien tulojen vuosikasvu tulokymmenyk- 
sittäin on kääntynyt päälaelleen ensimmäiseen jaksoon verrattuna. Ensimmäisen jakson aikana tulojen vuosikasvu oli sitä suurempaa mitä alhaisempi tulokymmenys ja toisen jakson aikana sitä suurempaa mitä hyvätuloisempi tulokymmenys. Varallisuutta ja sen jakautumista koskevat tiedot ovat huomattavasti puutteellisempia kuin tulotiedot, mutta erilaisten arvioiden mukaan ne noudattavat karkeasti samaa kaavaa kuin tuloerojen kehitys. Ylimpien varallisuusosuuksien kasvu on kiihtynyt 1990-luvun puolivälistä lähtien.

Suomessa viimeisimmät vakavat talouskriisit ajoittuvat globaalin kilpailuvaltion aikaan. 1990-luvun lamaa seurasi voimakas tulo- ja varallisuuserojen kasvu, joka pysähtyi hetkeksi globaalin finanssikriisin aikana, mutta on sen jälkeen palautunut aiempaa korkeammalle tasolle (Riihelä \& Tuomala 2020). Talouskriisit ovat myös osuneet porvarihallitusten valtakausille lukuun ottamatta Eurokriisin jälkimaininkien sateenkaarihallitusta ja koronakriisin aikaista keskustavasemmistolaista hallitusta.

Ylimpien tulo- ja varallisuusluokkien selviytyminen kriiseistä on monella tapaa mielenkiintoinen tarkastelun kohde. Se voi selittää sekä kaikkein varakkaimpien yksilöiden poliittista vaikutusvaltaa että talouspoliittisten järjestelmien sisäänrakennettuja toimintalogiikoita. Ylimpien tulo- ja varallisuusluokkien palautuminen kriiseistä on ollut viime vuosikymmeninä suhteellisen nopeaa. Esimerkiksi Yhdysvalloissa finanssikriisin jälkeisinä vuosina 2009-2012 rikkaimman prosentin tulot kasvoivat 31,4 prosenttia kun taas loppujen 99 prosentin tulot kasvoivat vain 0,4 prosenttia (Saez 2013, 0). Meneillään olevassa kriisissä varakkaimpien toipuminen näyttää alkaneen jo kriisin aikana.

Erilaiset kriisit vaikuttavat varallisuuteen eri tavoin. Esimerkiksi sodissa tuhoutuu fyysistä omaisuutta, kun taas jonkin talouden sektorin kuplautuminen voi johtaa kysynnän äkkinäiseen romahtamiseen ja omaisuuserien arvon nopeaan laskuun. Pandemiat ovat tässä suhteessa oma lukunsa.

\section{Pandemia talouskriisinä ja koronan vaikutukset tuloihin ja varallisuuteen}

Pandemia on taloudelle sodan kaltainen ulkoinen shokki, mutta se on sitä vain hieman keinotekoisessa mielessä, sillä sekä sodat että pandemiat liittyvät usein myös talouteen: sodat talouden resursseihin ja pandemiat sellaisiin tuotannon ja kuluttamisen tapoihin, jotka mahdollistavat tautien leviämisen muualta luonnosta tai, tässä tapauksessa epätodennäköisemmin, laboratorioista laajasti ihmisten keskuuteen. Pandemiat eroavat sodista siinä, että fyysistä omaisuutta ei oletusarvoisesti tuhoudu. Sen sijaan tuotannon ja kuluttamisen olosuhteet muuttuvat. Koronapandemian aiheuttama shokki maailmantaloudelle on johtunut sekä kysynnän että tarjonnan osittaisesta romahduksesta, kun ihmiset eivät ole erilaisista syistä kuluttaneet samalla tavalla kuin aikaisemmin. Palveluita ja tuotantolaitoksia on myös suljettu viruksen leviämisen rajoittamiseksi. Pandemian aiheuttamat olot ovat vaikuttaneet negatiivisesti ihmisten uskoon koskien talouden kehitystä lähitulevaisuudessa, mikä on lisännyt säästämistä ja vähentänyt investointeja.

Maailmatalouden tunnusluvut ensimmäiseltä koronavuodelta tarkentuvat edelleen. IMF:n viimeisin arvio huhtikuulta 2021 on, että maailmantalous supistui 3,3 prosenttia vuonna 2020. Supistuminen on pienempää kuin loppuvuonna ennakointiin, ja tämän arvioidaan johtuvan paremmasta koronatilanteesta ja rajoitusten höllentämisestä vuoden 2020 toisella puoliskolla. Rajoitusten uusista kiristyksistä huolimatta maailmatalouden arvioidaan rokotteiden myötä kasvavan vuonna 2021 kuusi prosenttia. (IMF 2021.)

Äärimmäinen köyhyys kasvaa ensimmäistä kertaa vuosikymmeniin ja taloudellisen epätasa-arvon on ennakoitu lisääntyvän. Koronakriisi uhkaa hävittää inhimillistä pääomaa erityisesti valmiiksi heikoimmassa asemassa olevien ihmisten keskuudessa, jolloin kriisin vaikutukset saattavat pitkittyä huomattavasti. On huomioitava, että koronakriisi ei ole vain negatiivinen piikki muuten positiivisessa kehityksessä. Esimerkiksi ilmastonmuutoksella ja aseellisilla konflikteilla on 
samankaltaisia seurauksia kuin koronapandemialla. (World Bank Group 2020.)

Pandemian alussa keväällä 2020 kotitalouksien nettotuloihin kohdistuneet shokit keskittyivät ainakin Yhdysvalloissa pienimpiin tuloihin, kun taas rahoitusvarallisuuden osalta suurin shokki kohdistui suurimpiin omaisuuseriin (Hanspal, Weber \& Wohlfart, 2020). Pandemian alun jälkeen erityisesti varallisuuden arvo on maailmanlaajuisesti palautunut monin paikoin pandemiaa edeltäneelle tai korkeammalle tasolle, miljardöörien omaisuus on kasvanut ja miljardöörien määrä lisääntynyt (Credit Suisse Research Institute 2020). ${ }^{1}$ Sen sijaan työttömyysluvut ovat maailmanlaajuisesti huomattavasti korkeammalla tasolla kuin ennen pandemiaa. Työtuntien määrä laski globaalisti 17 prosenttia vuoden 2020 toisella neljänneksellä työpaikkojen suluista johtuen. Eniten työtunteja ovat menettäneet alemman keskitulon maat. (ILO 2020.) Myös Yhdysvalloissa työttömyysprosentti oli lokakuussa 2020 lähes kaksi kertaa suurempi kuin samaan aikaan edellisenä vuonna. Työllisyys laski enimmillään 14,5 prosenttia ja yhdeksän kuukautta koronataantuman alun jälkeen työttömyys oli 6,5 prosenttia korkeampi kuin kriisin alussa (U.S. Bureau of Labor Statistics 2020). Suomessa työttömien määrä kasvoi helmikuun 2020 ja helmikuun 2021 välillä työvoimatutkimuksen arvion mukaan 35 ooo:lla (Suomen virallinen tilasto 2021).

Tutkimus- ja rahalaitoksissa on huomioitu vuoden 2020 erityislaatuinen kehitys. Rahoituspalveluita maailmanlaajuisesti tarjoava Allianz uutisoi vuoden 2020 varallisuusraportistaan otsikolla "Year of the Rich". Institute for Policy Studiesin Billionaire Bonanza 2020 -raportissa todetaan, että elämme sekä Yhdysvalloissa että globaalisti "miljardöörien vuosia". Seuraavaksi tarkastelen osakemarkkinoiden ja superrikaiden omaisuuden kehitystä koronapandemian aikana.

\section{Osakemarkkinat}

Osakemarkkinat ovat olleet koronakriisin aikana usein otsikoissa, sillä ne näyttävät palautuneen poikkeuksellisen nopeasti kevään ensimmäisestä shokista. Osakemarkkinoiden palautuminen on vaurauden resilienssin kannalta kiinnostavaa, sillä osakkeiden omistus on hyvin keskittynyttä. Esimerkiksi Yhdysvalloissa ylin tulokymmenys omistaa 87 prosenttia koko maan osakekannasta, kun alin 50 prosenttia puolestaan omistaa vain prosentin. Rikkain prosentti omistaa 52 prosenttia ja alin 90 prosenttia omistaa 13 prosenttia osakekannasta. Osakkeiden omistus on keskittynyt suureksi osaksi pienelle ryhmälle rikkaita valkoisia miehiä. (Oxfam 2020.) Omistusrakenne on Suomessakin saman suuntainen. Suomalaisista 12,8 prosenttia omisti osakkeita vuonna 2015 (Keloharju \& Lehtinen 2015). Edellä mainittu osuus on kasvanut koronakriisin aikana, mutta omistus on edelleen keskittynyttä. Vuonna 2015 rikkain prosentti suomalaisista omisti 77 prosenttia kaikesta investointivarallisuudesta. Vanhemmat miehet ovat omistajissa yliedustettuna. (Mt.)

On myös otettava huomioon, että institutionaalisten osakkeenomistajien määrä on noussut nopeasti. Yhdysvalloissa institutionaaliset toimijat omistivat julkisen osakekannan arvosta 1980-luvulla noin 26,8 prosenttia. Vuonna 2005 institutionaaliset osakkeenomistajat omistivat 60 prosenttia Yhdysvaltain tuhannesta suurimmasta yhtiöstä ja kattoivat 70 prosenttia kaikesta osakekaupasta. (Osagie, Osho \& Sutton 2005.) Vuonna 2017 institutionaaliset sijoittajat omistivat 78 prosenttia osakemarkkinoiden markkinaarvosta. Vastaava luku on Euroopassa S\&P Euro -indeksin perusteella 58 prosenttia. (Pensions \& Investments 2017.) Euroopassa osakekaupan markkina-arvo nousi hitaasti 1990-luvun alkuun asti ja on sen jälkeen noussut nopeasti erityisesti laajojen yksityistämisten seurauksena. Samaan aikaan institutionaalisten omistajien suhteellinen osuus on kasvanut nopeasti. (OEE \& IODS 2013.) Institutionaalisiin omistajiin kuuluu hyvin erilaisia toimijoita, kuten eläkeyhtiöitä, pankkeja ja vakuutusyhtiöitä. Omistuksen keskittyessä institutionaalisille toimijoille, voidaan taloudellisen vallan myös olettaa keskittyneen lisää.

Koronan levitessä osakemarkkinat romahtivat helmikuun ja maaliskuun 2020 aikana. "Toiseksi mustaksi maanantaiksi" nimettynä maaliskuun 16. päivänä suurin osa kansainvälisistä osakemarkkinoista koki 12-13 prosentin pudotuksen. 
Neljän kauppapäivän aikana Dow Jones Industrial Average -indeksi putosi 6400 pistettä, mikä vastaa noin 26 prosenttia (Mazur, Dang \& Vega 2020). Indeksi kävi keväällä 2020 alimmillaan alkuvuoden 2017 tasolla, mutta on tällä hetkellä kaikkien aikojen huipussaan (Macrotrends 2021).

Osakepääoma on suhteellisen volatiilia ja sen arvo saattaa heilahdella erilaisista pienemmistäkin syistä. Kevään tiputus oli kuitenkin historiallinen sekä sen rajuuden että nopean palautumisen takia. Erityisen kiinnostavan nopeasta selviytymisestä tekevät sen olosuhteet: tulevaisuuden näkymät olivat poikkeuksellisen synkät, jolloin tuotto-odotukset yleensä tippuvat ja osakekauppa hiipuu. Myös Credit Suissen Global Wealth Reportin mukaan osakemarkkinoiden hintojen muutokset indikoivat ensimmäisenä pandemian taloudellisia seurauksia: markkinat palautuivat vakuuttuessaan siitä, että valtiot reagoisivat tilanteeseen voimakkaasti huolimatta toimien seurauksista julkisen velan kehitykselle. (Credit Suisse Research Institute 2020, 5.) Myös pääomamarkkinoiden palautuminen nähdään raportissa valtioiden toimien ansiona (Credit Suisse Research Institute 2020,15$)$. Toisena markkinoiden luottamusta paaluttavana tekijänä toimi usko siihen, että korot säilyvät matalina vielä useita vuosia (Credit Suisse Research Institute 2020, 5).

Talouden kasvunäkymät ovat edelleen vahvat jopa vuosiksi eteenpäin. Muutoksia kuitenkin tapahtuu ja myös epävarmuuksia on ilmassa. Yksi kysymys on kuinka paljon eteenpäin katsovasta optimismista sisältyy jo markkinoiden hinnoitteluun. Toiseksi, mahdollinen verojen nousu ja esimerkiksi suunnitelmat globaalista yritysverosta saattavat aiheuttaa huolta markkinoilla. Kolmanneksi, elvytyshuipun jälkeen riskejä otetaan vähemmän ja varmempia osakkeita arvostetaan enemmän. (Mackenzie 2021.) Esimerkiksi kuumana käyvä mutta jo muutaman kerran markkinoilla tippunut teknologiateollisuus sisältää paljon epävarmuuksia ja spekulaatiota.

\section{Superrikkaat}

Forbesin julkaistessa listansa maailman rikkaimmista ihmisistä 18. maaliskuuta 2020, miljardööri- en määrä oli laskenut 58:lla vuoden takaisesta ja 226:lla kahdentoista päivän takaisesta tilanteesta. Jäljellä olevasta 2095:stä miljardööristä 51 prosentin varallisuus oli laskenut edellisestä vuodesta. Forbesin mukaan maailman rikkaimmat ihmiset eivät täten ole immuuneja koronavirukselle. (Forbes 2020.)

Käänne koronakriisin alun jälkeen tapahtui kuitenkin nopeasti. Sveitsiläisen UBS pankkikonsernin mukaan maailman miljardöörien omaisuus kasvoi 27,5 prosentilla huhtikuun ja toukokuun välisenä aikana. Sen lisäksi maailman miljardöörien määrä nousi uuteen ennätykseen, 2189:ään. (UBS 2020.) Samaan aikaan Maailmanpankki on arvioinut äärimmäisen köyhyyden kasvavan ensimmäistä kertaa kahteen vuosikymmeneen (World Bank Group 2020).

Palautumisessa on huomattavissa sektorikohtaisia eroja: varallisuuden arvo esimerkiksi autoja teknologiateollisuudessa palautui nopeammin kuin rahoitus- ja investointipääoma (Credit Suisse Research Institute 2020, 31). Nähtävissä on myös maakohtaisia eroja: miljardöörien omaisuus esimerkiksi Kiinassa, Japanissa ja Koreassa oli suurempi kesäkuun lopussa kuin helmikuussa. Global Wealth Reportin analyysin mukaan edellinen johtuu paljolti auto- ja teknologiateollisuuden merkityksestä kyseisissä maissa. Yhdysvalloissa miljardöörien omaisuus palautui suurin piirtein entiselleen ja eniten laskua oli Italiassa ja Isossa-Britanniassa. Edellä viitatut tiedot koskevat vuoden 2020 kahta ensimmäistä neljännestä ja sittemmin esimerkiksi yhdysvaltalaisten miljardöörien omaisuus on jatkanut kasvuaan. Global Wealth Reportin tietojen mukaan eniten omaisuuttaan kasvattivat kaikista vauraimmat miljardöörit, joiden omaisuus kasvoi 18. maaliskuuta ja 30. kesäkuuta välisenä aikana noin viidelläkymmenellä prosentilla. Monet heistä ovat suurten teknologiayritysten omistajia. (Credit Suisse Research Institute 2020, 31-32.)

Yhdysvalloissa miljardöörien omaisuus kasvoi pandemian ensimmäisten yhdeksän kuukauden aikana 1,065 biljoonalla dollarilla, eli 36 prosentilla. Miljardöörien määrä kasvoi 614:sta 651:een. Samaan aikaan 67 miljoonaa ihmistä menetti työnsä. Yhdysvalloissa koronapandemia on kiih- 
dyttänyt kehitystä, jossa varallisuus keskittyy kiihtyvällä tahdilla ylimmille tulo- ja varallisuusluokille. Joulukuussa 2020 yhdysvaltalaisten miljardöörien varallisuus oli 4 biljoonaa ja koko kansan huonompituloisen puolikkaan varallisuus 2,36 biljoonaa. (Billionaires by the Numbers 2020.)

Myös miljoonaomaisuuksia omistavista voidaan tehdä kiinnostavia havaintoja koronapandemian ajalta. Miljonäärien määrä muuttui Global Wealth Reportin estimaattien mukaan vuoden 2020 ensimmäisellä puoliskolla hyvin vähän. Vuonna 2019 miljonäärien määrä kohosi rajusti, ja vuoden lopussa heitä oli maailmassa noin 51,9 miljoonaa. Miljonäärien määrän pysyminen suurin piirtein ennallaan viittaa myös osaltaan vaurauden resilienssiin; vaikka miljonäärien määrän kasvu hidastui huomattavasti edelliseen vuoteen verrattuna, ei se kuitenkaan laskenut merkittävästi. Sen sijaan muutoksia miljonäärien kokoonpanossa on pandemian seurauksena tapahtunut poikkeuksellisen paljon. Pandemian aiheuttamat olosuhteet ovat suosineet toisia ja kurittaneet toisia, ja esimerkiksi valuuttakurssien muutokset ovat vaikuttaneet hyvinkin negatiivisesti joihinkin maihin. Vuoden 2020 suurin lasku miljonäärien määrässä tapahtui Iso-Britanniassa, Brasiliassa ja Kanadassa. Selvästi suurin nousu tapahtui Kiinassa, ja miljonäärien määrä kasvoi hieman myös esimerkiksi Yhdysvalloissa ja Alankomaissa. (Credit Suisse Research Institute 2020, 33-34.) Erityisesti kaikkein rikkaimpien ihmisten kohdalla resilienssi vaikuttaa ainakin osin yksilökohtaiselta, kun taas miljonäärien kohdalla vaurauden resilienssi on rakenteellisempaa. Miljonäärikategoriassa yksilöt saattavat vaihtua olosuhteiden muuttuessa, mutta vaurauden rakenteellinen jakautuminen muuttuu vähän.

\section{Syitä ja seurauksia}

Seuraavaksi esitän kolme erilaista selitysmallia edellä käsitellyille kehityskuluille. Selitysmallit ovat toisiaan täydentäviä, mutta niiden suhteellisen selitysvoiman arviointi jää kattavamman analyysin tavoin tuonnemmaksi. Ensiksi, tiettyjen omaisuusluokkien menestyminen koronakriisissä ei niinkään indikoi vaurauden yleistä selviyty- miskyvykkyyttä vaan on seurausta kriisin erityisluonteesta. Kriisin erityisluonne on vahvistanut esimerkiksi tieto- ja viestintäteknologiayritysten asemaa ja kansainvälisten teknologiayritysten monopolisoitumiskehitystä. Toiseksi, kapitalismin historiallis-institutionaalinen kehityskulku on tuottanut olosuhteet, joissa ensisijaisesti käytettävissä olevat talouden tuki- ja suojaustoimet ikään kuin automaattisesti hyödyttävät suuria omaisuuseriä. Keskuspankkien passiivisesti suuntautuva kysynnän ylläpito on mahdollisesti kasvattanut valmiiksi rikkaiden varallisuutta. Kolmanneksi, kapitalismin muodot selittävät poliittisen toimijuuden jakautumista koronahallinnassa, mikä puolestaan selittää julkisten tukitoimien implementointia eri maissa. Plutokraattisemmissa poliittisissa olosuhteissa pääoman edustus ja edut ovat vahvemmat.

\section{Globaali teknomonopolisaatio}

Kriisistä on hyötynyt kaikista selvimmin skaalautuviin töihin ja palveluihin liittyvä suurpääoma. Skaalautuvuus on ilmiö joka liittyy erityisesti teknologian kehitykseen ja globalisaatioon. Skaalautuvuus pätee erityisesti immateriaalisiin hyödykkeisiin: pasta-annoksen voi myydä vain kerran mutta jooga-tutoriaalin rajattoman monta kertaa. Esimerkiksi verkkokauppa ja erilaiset verkon yhteisöpalvelut näyttävät keskittyvän kiihtyvällä tahdilla. Yleistyessään ilmiö johtaa taloudellisen epätasa-arvon kasvuun (Milanovi» 2016, 223-226).

Kapitalismin taipumus tuottaa monopoleja ja oligopoleja saa verkossa täysin uudenlaiset mittasuhteet. Havainnot kriisin ajalta osoittavat, että pandemia on kiihdyttänyt olemassa ollutta kehitystä. Verkossa toimivat teknojätit ovat hyötyneet pandemiaolosuhteista, mikä on kiihdyttänyt pääoman kasautumista. Superrikkaiden joukossa on useita teknologiajättien edustajia.

Oxfam (2020) raportoi heinäkuussa, että 25 suurinta yhdysvaltalaisyhtiötä oli tehnyt kriisin aikana keskimäärin 11 prosentin voittoa, kun taas pienten yritysten tuotto oli tippunut keskimäärin viisikymmentä prosenttia. Suurimpien yhtiöiden kärkikastiin kuuluvat esimerkiksi Visa, Microsoft, Pfizer, Intel, Facebook, Oracle, AbbVie ja Apple. 
Yhtiöt jotka tekivät vuonna 2020 suuria voittoja, olivat jo valmiiksi maailman kannattavimpia liikeyrityksiä. Oxfamin mukaan taloudellinen etulyöntiasema on helppo muuttaa ylivallaksi kriisiolosuhteissa (Oxfam 2020, 5).

\section{Keskuspankkikapitalismin perusasetukset}

Vaurauttaan koronapandemian aikana kasvattaneisiin tai sen arvoa säilyttäneisiin omistajiin kuuluu myös muita kuin niitä, joiden liiketoiminta on sattunut hyötymään pandemian aiheuttamista olosuhteista. Tämä pätee niin suurituloisiin osakkeen omistajiin kuin keskituloisempiin asunnon omistajiin. Global Wealth Reportissa $(2020,6)$ kotitalouksien vaurauden arvon säilymisen syiksi nimetään muun muassa matalat korot ja valtioiden massiiviset elvytystoimet, jotka ovat ruokkineet optimismia markkinoilla. Taustalla vaikuttaa raportin mukaan muun muassa se, että hallitukset ja keskuspankit ovat oppineet luottojärjestelyiden ja määrällisen keventämisen tärkeyden vakavassa kriisissä (Credit Suisse Research Institute 2020, 19). Määrällinen keventäminen tarkoittaa keskuspankin rahapoliittista operaatiota, jossa se ostaa markkinoilta erilaisia rahoitusinstrumentteja ja näin ollen nostaa niiden kysyntää ja hintoja. Kiinnostavaa tässä on erityisesti keskuspankkien rooli: on yhä kiistanalaista, minkälaisten mekanismien kautta keskuspankkien rahapolitiikka on mahdollisesti vaikuttanut myös vaurauden resilienssiin.

Koronakriisin hoidossa eri maiden toimien välillä on valtavia eroja, mikä johtunee ainakin osittain niiden rahapoliittisen suvereniteetin asteesta, joka puolestaan vaikuttaa niiden rahoitusasemaan. Eri valtioilla on erilaiset mahdollisuudet keskuspankkirahoitukseen tai velkaantumiseen. Rahapoliittiseen suvereniteettiin vaikuttaa muun muassa se, onko valtiolla oma keskuspankki ja oma raha, ja onko se velkaantunut ulkomaisessa valuutassa. Esimerkiksi Euroopan talous- ja rahaliittoon kuuluvat valtiot eivät ole rahapoliittisesti suvereeneja, koska ne ovat luovuttaneet rahapolitiikkansa Euroopan keskuspankin hoidettavaksi. Liiton sääntöjä on kuitenkin korona- kriisin aikana muutettu siten, että muun muassa alijäämiä ja velkasuhteita rajoittava Euroopan vakaus- ja kasvusopimus on ainakin väliaikaisesti jäähyllä. Sääntöjen muuttaminen antaa sopimukseen kuuluville valtioille fiskaalista liikkumatilaa. Eurooppalaisten valtioiden alijäämäinen kulutus onkin lisääntynyt, mutta pelko paluusta fiskaaliseen konservatismiin saattaa hillitä halukkuutta käyttää hyväksi sääntöjen hölläämistä. Monilta köyhemmiltä valtioilta merkittävä fiskaalinen liikkumatila puolestaan puuttuu, eli niiden on vaikeampaa rahoittaa julkisten kulujen lisäämistä. Näin ollen erilaiset mahdollisuudet elvyttää pandemian jälkeen saattavat kasvattaa globaalia eriarvoisuutta, ja myös esimerkiksi estää ekologisen jälleenrakennuksen mahdollisuuksia suuressa osassa globaalia etelää (Lenferna 2020).

Vaikka finanssipolitiikan rooli on varsinkin pandemian alun jälkeen vahvistunut, erityisen kiinnostavaa vaurauden resilienssin kannalta on keskuspankkien valmiiksi suuren roolin kasvu entisestään. Keskuspankkien rooli on kasvanut erityisesti vuosien 2007-2009 finanssikriisin jälkeen. Liian vähäinen kokonaiskysyntä maailmantaloudessa ja yksityisen sektorin vähäinen lainanottohalukkuus ovat pakottaneet keskuspankit ylläpitämään kysyntää ja halvan rahan tarjontaa². Kyseistä ilmiötä on kutsuttu keskuspankkikapitalismiksi (Ahokas 2019). Koronapandemian alkaessa maailmantalouden toimijat, valtiot mukaan lukien, olivat tottuneet keskuspankkien uuteen vahvistuneeseen rooliin ja suuri vastuu kysynnän ja rahavirtojen ylläpitämisestä sälyttyi ikään kuin oletusarvoisesti keskuspankkien vastuulle. Korot olivat kuitenkin jo valmiiksi alhaalla ja globaali pandemia järkytti markkinatoimijoiden uskoa tulevaisuuteen, mikä laski velkaantumishaluja entisestään.

Rahapolitiikan tehoa kyseenalaistettiin jo ennen koronakriisiä. Aggressiivista rahapoliittista keventämistä on kutsuttu esimerkiksi narulla työntämiseksi, sillä halvan rahan tarjonta ei auta, jos velanottohalukkuutta ei ole (ks. esim. Koo 2019). Valtioiden kohdalla vaikuttimena saattaa olla myös pelko, että velkaantuminen asettaa ne myöhemmin poliittisen altavastaajan asemaan, kun kuria mahdollisesti taas vaaditaan. Julkisen 
velanoton tai suoran keskuspankkirahoituksen pelko on juurtunut syvälle politiikkaan ja koronakriisissäkin talouspoliittiset kriisitoimet ovat siksi jääneet monin paikoin vahvasti keskuspankkien harteille. Keskuspankkien kriisiä edeltänyt viesti siitä, että hallitusten on otettava enemmän vastuuta, on kriisin aikana jatkuvasti vahvistunut (ks. esim. Reuters 2020). Erityisesti Yhdysvallat on kasvattanut finanssipolitiikan roolia aivan viime aikoina. Saatammekin olla siirtymässä voimakkaamman valtiokapitalismin aikaan (Ahokas 2021).

Suurten omaisuuserien resilienssin kannalta kiinnostavia ovat viitteet siitä, että keskuspankkien elvyttävä rahapolitiikka hyödyttäisi erityisesti pääomatulojen saajia (ks. esim. Seccareccia 2017). Tämä on kuitenkin tarinan epäselvin osuus. Usein toistettu väite, että kevyt rahapolitiikka valuu suoraan osakkeisiin, on osittain kyseenalaistettu. Esimerkiksi Nathan Tankusin (2020) mukaan ihmiset puhuvat jatkuvasti siitä, mitä osakemarkkinoilla tapahtuu, kun he käytännössä tarkoittavat sitä, mitä oskemarkkinaindikaattoreissa tapahtuu. Huomio osakekurssien noususta pandemian aikana johtuu Tankusin mukaan suureksi osaksi siitä, että osakekursseja mitataan indekseillä, jotka ovat osakemarkkinoiden aggregaattimittareita. Indeksirahastot toimivat näiden indeksien informaation varassa. Pandemian aikana paljon myydyillä ja osittain yliarvostetuilla teknologiafirmojen osakkeilla on suuri vaikutus näissä indekseissä. Näin ollen osakemarkkinat eivät välttämättä ole niin erillään reaalitaloudesta kun usein väitetään. Teknologiaosakkeiden ja indeksirahastojen korkealla arvolla olisi tässä tapauksessa vaikutusta eriarvoisuuden kasvuun osakkeiden keskittyneen omistukseen kautta mutta ei vaurauden yleiseen resilienssiin rahapolitiikan kautta.

Indeksirahastojen niin sanottu passiivinen sijoitusmalli on ollut pitkään kasvava ilmiö ja niissä kiinni olevan rahoitusvarallisuuden arvo ylitti vuoden 2019 puolessa välissä ensimmäistä kertaa aktiivisesti hallinnoitujen rahastojen osuuden. Indeksirahastojen passiivisen toiminnan takana indeksien rakentajilla on paljon valtaa ja ne käytännössä hallinnoivat sitä, mihin kohteisiin rahaa sijoitetaan. (Petry, Fichtner \& Heemskerk 2020.)
Tankusin huomioista huolimatta voidaan myös esittää keskuspankkikapitalismin ajan rahapolitiikan vaikuttavan vaurauden resilienssiin. Tähän on erilaisia mahdollisia väyliä: 1) Valtion velkakirjojen kysynnän ja siten arvon pitäminen ylhäällä määrällisen keventämisen avulla. Myös valtion velkakirjojen omistus on keskittynyttä. 2) Matalien korkojen olosuhteissa suursijoittajien on mahdollista käyttää velkavipua osakepääomansa kasvattamiseksi ja samalla pumpata hintoja ylöspäin. 3) Markkinoiden toiminnan aktiivisen fasilitoinnin vaikutus niin sanottuihin eläimellisiin vaistoihin ja tulevaisuuden odotuksiin: vaikka reaalitalouden toiminta olisi osittain estynyt, finanssitalouden toimijoiden usko tulevaan voisi aktiivisten toimien myötä säilyä.

Esimerkiksi Montecino ja Epstein (2015) ovat havainneet, että vaikka määrällinen keventäminen vahvistaa esimerkiksi työllisyyttä, se kasvattaa vielä enemmän omaisuuksien arvoa, ja siten taloudellista epätasa-arvoa. Mikäli keskuspankkien toiminta vahvistaa osakekursseja, kuten Global Wealth Reportistakin voisi päätellä, hyötyvät siitä eniten jo valmiiksi varakkaat tahot. Kuten aiemmin mainittu, osakkeiden omistus on keskittynyt suhteellisen pienelle varakkaalle joukolle. Halpaa velkarahaa käytetään myös esimerkiksi asuntojen hankintaan. Halpaa velkarahaa saa sitä helpommin, mitä suurempi pesämuna on valmiiksi. Esimerkiksi Suomessa asuntokauppaa on koronan aikana tehty jopa ennätystahtiin (Niiranen 2020). Ensiasunnon ostajien määrä on kuitenkin laskenut jo ennen koronaa, ja ammattimaiset sijoittajat hallitsevat asuntomarkkinoita yhä vahvemmin (Roslund \& Ali-Hokka 2020).

Vaikka keskuspankkikapitalismilla olisi jo valmiiksi varakkaita tahoja hyödyttäviä vaikutuksia, olisi rahapolitiikan kiristämisellä huonoja seurauksia myös työntekijöille, sillä se heijastuisi negatiivisesti reaalitalouteen. Vaikka esimerkiksi matalat korot eivät itsessään lisää investointeja, olisivat korkeammat korot investoijille vielä suurempi riski epävarmoissa oloissa ja lisäksi kannustimet säästämiseen kasvaisivat. Siksi kapitalismin sisällä vastauksia varallisuuden kasautumisen kiihtymiseen ja taloudelliseen epätasa-arvoon puuttumiseen on mahdollisesti et- 
sittävä rahapolitiikan ulkopuolelta, esimerkiksi finanssipoliittisesta aktivismista, kuten sosiaalisista investoinneista, tulojen turvaamisesta ja varallisuusveroista. Laajempiin institutionaalisiin uudistusehdotuksiin kuuluu keskuspankkien voimakkaampi demokraattinen ohjaus. On toki huomioitava, että vaikka teknokraattista rahapolitiikkaa usein perustellaan sillä, että se toimii, keskuspankkien mandaatti tulee silti valtioilta, joiden tahtoa ne myös pääasiassa toteuttavat. Tarina itsenäisestä keskuspankista on siis osittain myytti.

\section{Plutokraattien protektionismi}

Oxfamin (2021) mukaan pandemia on ympäri maailman vaikuttanut vähiten kaikista rikkaimpiin. Maailman vauraimmilla henkilöillä on huomattava määrä poliittista vaikutusvaltaa. Taloudellisen vallan ja poliittisen vallan yhteyteen on kiinnitetty enenevissä määrin huomiota kuluneiden vuosikymmenten aikana. Branco Milanovisin (2016) globaaleiksi plutokraateiksi kutsumalla miljardööriluokalla on taloudellista valtaa erityisen paljon. Miljardöörit ovat myös maantieteellisesti keskittyneitä. Vuoden 2020 maaliskuussa maailman 2095:stä miljardööristä 614 oli Yhdysvaltalaisia (Forbes 2020).

Yhdysvalloissa taloudellisen eriarvoisuuden kasvun ja varallisuuden keskittymisen kaikista rikkaimmille on todettu useaan otteeseen olevan ristiriidassa demokraattisen kehityksen kanssa. APSA Task Force on Inequality and American Democracy totesi vuonna 2004, että meneillään olevat trendit tekevät Yhdysvaltojen poliittisesta järjestelmästä responsiivisen pääasiassa kaikista parhaiten toimeentulevalle väestönosalle (American Political Science Association 2004). Taloudellisen epätasa-arvon kasvu tarkoittaa myös poliittisen epätasa-arvon kasvua (Solt 2008).

Yksi indikaatio vaurauden merkityksen kasvusta yhdysvaltalaisessa politiikassa on vaalien jatkuva kallistuminen. Lobbauksella ja siihen laitetuilla rahamäärillä on suuri merkitys sen suhteen mille tahoille rahaa jaetaan, mutta niin on myös sillä mitä taloudellista luokkaa poliitikot edustavat. Vuoden 2012 vaaleissa paikka Yhdysvaltain edustajainhuoneessa maksoi keskimäärin
1689580 dollaria ja paikka senaatissa keskimäärin 10476451 dollaria (Costa 2013). Yhdysvalloissa poliittinen luokka on länsimaiden mittapuulla poikkeuksellisen varakasta keskimääräiseen kansalaiseen nähden. Sama trendi on kuitenkin yleinen myös kansainvälisesti.

Taloudelliset tukitoimet koronapandemian aikana ovat osoitus siitä, mitä edellä kuvattu rikkaiden valta käytännössä tarkoittaa. Robert Brenner (2020) on käynyt läpi yhdysvaltalaista tukipolitiikkaa koronapandemian alussa: Presidentti Donald Trump allekirjoitti maan ensimmäisen lainoja ja suoria tukia sisältäneen koronatukipaketin 27.3.2020. Historiallisen kokoisesta tukipaketista noin 75 prosenttia, eli noin 4,586 biljoonaa dollaria, päätyi lopulta maan suurimmille ja menestyneimmille yhtiöille. Samaan aikaan työttömyys kasvoi räjähdysmäisesti, mutta vain 603 miljardia yllä mainitusta paketista allokoitiin suorina tukimaksuina yksilöille ja perheille, työttömyysvakuutuksen parantamiseen ja opintolainoihin. (Brenner 2020, 7.) Tukitoimet toteutettiin yhteisymmärryksessä demokraattien ja republikaanien kesken. Sittemmin tukia on toki jaettu muidenkin kanavien kautta, ja myös vähävaraisemmille on suunnattu lisätukia. Presidentti Joe Bidenin talouspoliittinen linja vaikuttaa puolestaan muotoutuvan yhdysvaltalaisittain poikkeuksellisen progressiiviseksi.

Kapitalismin varianttien välillä on kuitenkin eroja. Jos maassa on suhteellisen universaali institutionalisoitu sosiaaliturva ja terveydenhuolto, kanavoituu tuki näihin kohteisiin olemassa olevien rahoituskanavien kautta erillisten tukipakettien sijaan. Tämä saattaa hillitä epätasa-arvon kasvua, mutta ei poista vaurauden resilienssin mekanismeja.

Resilienssi onkin nähtävissä myös esimerkiksi Euroopassa, jossa ginikertoimen on arvioitu nousevan keskimäärin 3,5-7,3 prosenttia (Palomino, Rodríguez \& Sebastian 2020). Vauraat tahot ovat täälläkin pystyneet hyödyntämään valtioiden koronatukia. Suuret yritykset ovat jakaneet valtavia osinkoja samaan aikaan kun ne ovat nostaneet yritystukia tai lomauttaneet työntekijöitä. Esimerkiksi BMW maksoi 1,6 miljardia osinkoja, samalla kun haki tukiaisia Saksan valtiolta. Ranskassa 
monet suuret yhtiöt ovat maksaneet suuria osinkoja samalla nostaen valtion tukia. (Oxfam 2020, 25-27.) Myös esimerkiksi suuret lentoyhtiöt ovat saaneet kymmenien miljardien tuet ilman sitovia velvoitteita päästöjen vähennyksiin (Greenpeace 2020). Brittien hallituksen "lomautusmiljoonista" ovat puolestaan saaneet osansa superrikkaat saudiprinsseistä veropakolaisiin (Davies \& Smith 2021).

\section{Voimattomat ideat?}

Koronaviruksen aiheuttama shokki kapitalistiselle maailmantaloudelle aloitti keväällä 2020 välittömän taistelun ideoista joilla pyrittiin määrittämään koronahallintaa (Huotari \& Teivainen 2020). Ideoiden skaala julkisessa tilassa laajeni merkittävästi pandemian ensimmäisten kuukausien aikana. Sittemmin toteutuneet koronahallinnan muodot ovat osoittaneet kuinka vahva resilienssi keskittyneellä vauraudella ja kapitalistisella maailmantaloudella on. Tässä puheenvuorossa olen ehdottanut resilienssin syiksi tiettyjä globaalin monopolikapitalismin muotoja, joita koronakriisi on hyödyttänyt, keskuspankkikapitalismin tulonjaollisia vaikutuksia ja vauraiden tahojen poliittista toimijuutta ja vahvaa edustusta politiikassa. Taustalla vaikuttaa myös pitkään jatkunut markkinoiden ja pääoman vapaamman toiminnan poliittinen fasilitointi.

Vaikka koronakriisin hoitoa näyttävät määrittävän sitä edeltäneet olosuhteet ja kehityskulut, ei julkisuuden avautuminen poikkeuksellisten ideoiden ja diskurssien kehitykselle ole välttämättä merkityksetön häiriö. Jo ennen koronapandemiaa näkyvyyttä saaneet ideat ja vaatimukset kapitalismin uudistamisesta saattavat hyvinkin saada kriisistä lisäpontta ja samalla tehdä tilaa radikaalimmille kapitalismin ylittäville ideoille. Jos yhteiskunnan varakkaimpien jäsenten omaisuus kasvaa samalla kun äärimmäinen köyhyys, nälkä ja työttömyys lisääntyvät, ei protestimielialan kasvaminen olisi tavaton seuraus.

Sekä eliittidiskurssin ulkopuolisten ideoiden että erilaisten kokeilujen merkitys paljastuu vasta tulevaisuudessa. Koronahallinta herättää kysymyksiä siitä mikä on taloudellisesti mahdollista.
Jos kodittomuus voidaan poistaa muiden suojelemiseksi tartunnoilta, miksei kodittomuutta poistettaisi pysyvästi? (Garcia 2020). Jos talous voidaan pitää pyörimässä pumppaamalla keskuspankkirahaa sisään järjestelmään, mikä estää ekologisen jälleenrakennuksen rahoittamisen samaan malliin? Ideoiden realisoituminen vaatii usein monta edeltävää vaihetta, joissa liikevoima kasvaa ja tuottaa lopulta tarpeeksi painetta ja näkyvyyttä, jotta ideoista tulee potentiaalisia politiikkatoimien osia. Yllättävillä yhteiskunnallisilla kriiseillä voi olla näissä prosesseissa suurikin merkitys.

VTM PAULI HUOTARI on maailmanpolitiikan tohtorikoulutettava Helsingin yliopistossa.

\section{VIITTEET}

1 Credit Suisse Research Instituten kotitalouksien varallisuutta ja varallisuusmuutoksia koskevan vuoden 2020 väliraportin tiedot kattavat vain vuoden kaksi ensimmäistä neljännestä ja nekin tarkentuvat vielä 2021 toisella neljänneksellä julkaistavassa koko raportissa.

2 Korkotaso on aina rahapoliittinen muuttuja, eli keskuspankki päättää korkotason.

\section{KIRJALLISUUS}

Ahokas, Jussi (2019) "Kapitalismin muodot ja institutionaalinen muutos - Kohti keskuspankkikapitalismia”. Politiikasta, https://politiikasta.fi/kapitalismin-muodotja-institutionaalinen-muutos-kohtikeskuspankkikapitalismia/ Viitattu 15.1.2021.

Ahokas, Jussi (2021) "Keskuspankkikapitalismi ajautui kriisiin. Siksi kapitalismin seuraava vaihe saattaa olla jo täällä”. Voima, https://voima.fi/artikkeli/2021/ keskuspankkikapitalismi-ajautui-kriisiin-siksikapitalismin-seuraava-vaihe-saattaa-olla-jo-taalla/ Viitattu 9.6.2021.

American Political Science Association (2004) "American Democracy

in an Age of Rising Inequality”. Task Force on Inequality and American Democracy, https://www.apsanet. org/portals/54/Files/Task\%20Force\%20Reports/ taskforcereport.pdf Viitattu 15.1.2021. 
Balestra, Carlotta \& Tonkin, Richard (2018) "Inequalities in household wealth across OECD countries: Evidence from the OECD Wealth Distribution Database”. OECD Statistics Working Papers 2018/01. OECD Publishing, Pariisi, https://read.oecd-ilibrary.org/economics/ inequalities-in-household-wealth-across-oecdcountries_7e1bf673-en\#page1 Viitattu 12.1.2021.

Billionaires by the Numbers (2020). https:/ americansfortaxfairness.org/billionaires/ Viitattu 13.1.2021.

Brenner, Robert (2020) "Escalating Plunder". New Left Review, 123:2, 5-24.

Camacho, Máximo \& Palmieri, Gonzalo (2019) ”Do economic recessions cause inequality to rise?". Journal of Applied Economics, 22:1, 304-320.

Costa, Jay (2013) "What's the Cost of a Seat in Congress?". MapLight. https://maplight.org/story/whats-the-cost-ofa-seat-in-congress/ Viitattu 14.1.2021.

Credit Suisse Research Institute (2020) "Global wealth report 2020".

Davies, Rob \& Smith, Joseph (2021) "The foreign royals and billionaire tax exiles collecting UK's furlough millions". The Guardian. https://www.theguardian.com/ uk-news/2021/mar/19/the-foreign-royals-and-billionairetax-exiles-collecting-uks-furlough-millions Viitattu 14.4.2021.

Forbes (2020) "World's Billionaires List. The Richest in 2020". https://www.forbes.com/billionaires/ Viitattu 12.1.2021.

Garcia, Francisco (2020) "Coronavirus nearly ended homelessness in the UK. Why can't we end it for good?". The Guardian, https://www.theguardian.com/ commentisfree/2020/jun/11/coronavirus-homelessnessuk-rough-sleepers-lockdown-tories Viitattu 14.1.2021.

Greenpeace (2020) "Airline bailouts set to double to €26bn as countries fail to impose binding green conditions". Greenpeace European Unit. https://www.greenpeace.org/ eu-unit/issues/climate-energy/2793/airlines-pollutersbailouts-double-to-26bn-without-binding-greenconditions/ Viitattu 14.4.2021.

Hanspal, Tobin \& Weber, Annika \& Wohlfart, Johannes (2020) "Exposure to the COVID-19 Stock Market Crash and its Effect on Household Expectations". CEBI Working Paper Series, No. 13/20.

Huotari, Pauli \& Teivainen, Teivo (2020) "Democratic horizons in times of corona governance". OpenDemocracy, https://www.opendemocracy.net/en/ openmovements/democratic-horizons-times-coronagovernance/ Viitattu 15.1.2021.

ILO (2020, syyskuu 23) "ILO Monitor: COVID-19 and the world of work. Sixth edition". https://www.ilo. org/wcmsp5/groups/public/@dgreports/@dcomm/ documents/briefingnote/wcms_755910.pdf Viitattu
12.1.2021.

IMF (2020) "A Crisis Like No Other, An Uncertain Recovery". World Economic Outlook Update, June 2020.

IMF (2021) " Managing Divergent Recoveries”. World Economic Outlook Update, April 2021.

Keeley, Brian (2015) "What's happening to income inequality?”. Julkaisussa Income Inequality: The Gap between Rich and Poor. OECD Publishing, Pariisi, 31-39, https://www.oecd-ilibrary.org/ docserver/9789264246010-4-en.pdf?expires $=161044832$ $1 \&$ id=id\&accname=guest $\&$ checksum $=404$ C403CD90B C99980DD5D6CF4C0F29B Viitattu 12.1.2021.

Keloharju, Matti \& Lehtinen, Antti (2015). "Shareownership in Finland 2015". Nordic Journal of Business, 64:3, 182-206.

Kiander, Jaakko (2001) Laman opetukset: Suomen 1990-luvun kriisin syyt ja seuraukset. Valtion taloudellinen tutkimuskeskus, Helsinki. https:// www.doria.fi/bitstream/handle/10024/148629/j27-5. pdf?sequence=1 Viitattu 12.1.2021.

Koo, Richard (2019) "Why aggressive monetary easing is pushing on a string". Financial Times. https://www. ft.com/content/e8bc69c2-d2d9-11e9-8367-807ebd53ab77 Viitattu 15.1.2021.

Lenferna, Alex (2020) "The Solution to the Coronavirus Recession Is a Global Green New Deal”. Jacobin. https:// jacobinmag.com/2020/04/coronavirus-global-greennew-deal-south-postcolonial Viitattu 13.4.2021

Mackenzie, Michael (2021) "Markets test how far to price in an economic boom". Financial Times. https://www. ft.com/content/ee0f1e7c-6f08-4072-b42b-9947237e7e7f Viitattu 12.4.2021.

Macrotrends (2020) "Dow Jones - DJIA - 100 Year Historical Chart". https://www.macrotrends.net/1319/dow-jones100-year-historical-chart Viitattu 15.1.2021.

Mazur, Mieszko \& Dang, Man \& Vega, Miguel (2020) "COVID-19 and the march 2020 stock market crash: Evidence from S\&P1500". Finance research letters, 101690. Advance online publication. https://doi. org/10.1016/j.frl.2020.101690

Milanović, Branco (2016) Global inequality: A new approach for the age of globalization. The Belknap Press of Harvard University Press. Cambridge.

Montecino, Juan Antonio \& Epstein, Gerald (2015) "Did Quantitative Easing Increase Income Inequality?". Political Economy Research Institute, University of Massachusetts Amherst, Working Paper Series, No. 407.

Niiranen, Pekka (2020) "Asuntokauppaa tehdään nyt maski kasvoilla jopa ennätystahtiin - ihmisten ostohalut näkyvät myös pankkien lainatiskeillä”. Yle uutiset. https://yle.fi/uutiset/3-11713262 Haettu 13.4.2021. 
Palomino, Juan C., Rodríguez, Juan G. \& Sebastian, Raquel (2020) "Wage inequality and poverty effects of lockdown and social distancing in Europe". European Economic Review, Volume 129.

Pensions \& Investments (2017) “80\% of equity market cap held by institutions". https://www.pionline.com/ article/20170425/INTERACTIVE/170429926/80of-equity-market-cap-held-by-institutions Viitattu 29.4.2021.

Piketty, Thomas (2014) Capital in the twenty-first century. Cambridge Massachusetts: The Belknap Press of Harvard University Press.

Riihelä, Marja \& Tuomala, Matti (2020) "Tulo- ja varallisuuserot". Teoksessa Eriarvoisuuden tila Suomessa 2020 (toim. Maija Mattila). Kalevi Sorsa -säätiö. Helsinki.

Roslund, Riku \& Ali-Hokka, Anne (2020) "Ensiasunnon ostajien määrä vähenee, sijoittajat vievät parhaat päältä - Insinööri: 'Moni mun kaveri ei enää edes haaveile omistusasunnosta"'. Yle uutiset. https://yle.fi/ uutiset/3-11647434 Viitattu 13.4.2021.

Saez, Emmanuel (2013) "Striking it Richer: The Evolution of Top Incomes in the United States (Updated with 2012 preliminary estimates)". UC Berkeley, https:// eml.berkeley.edu/ saez/saez-UStopincomes-2012.pdf Viitattu 12.1.2021.

Seccareccia, Mario (2017) "Which Vested Interests Do Central Banks Really Serve? Understanding Central Bank Policy Since the Global Financial Crisis". Journal of Economic Issues, 51:2, 341-350.

Stiglitz, Joseph E. (2013) The Price of Inequality. W.W. Norton \& Company. New York.

Suomen virallinen tilasto (2021) "Työvoimatutkimus" [verkkojulkaisu]. ISSN=1798-7830. Helsinki: Tilastokeskus [viitattu: 12.4.2021]. Haettu osoitteesta: http://www.stat.fi/til/tyti/

Solt, Frederick (2008) “Economic Inequality and Democratic Political Engagement”. American Journal of Political Science, 52:1, 48-60.

Tankus, Nathan (2020) “The Stock Market Is Less Disconnected From the 'Real Economy' Than You Think: Stock Market Indices Aren't The Stock Market”. Notes on the Crises. Substack. https://nathantankus. substack.com/p/the-stock-market-is-less-disconnected Viitattu 29.4.2021.

UBS (2020) "Riding the Storm. Market Turbulence Accelerates Diverging Fortunes". Billionaires insights 2020. https://www.pwc.ch/en/publications/2020/UBSPwC-Billionaires-Report-2020.pdf Viitattu 15.1.2021.

U.S. Bureau of Labor Statistics (2020) "Employment recovery in the wake of the COVID-19 pandemic". https://www.bls.gov/opub/mlr/2020/article/employmentrecovery.htm Viitattu 15.1.2021.
OEE \& IODS (2013) "Who Owns the European Economy? Evolution of the Ownership of EU-Listed Companies Between 1970 and 2012". https://ec.europa.eu/info/ sites/default/files/file_import/1308-report-who-ownseuropean-economy_en_0.pdf Viitattu 29.4.2021.

Osagie, Johnston, Osho, Gbolahan S. \& Sutton, Cynthia (2005) "The Impacts Of Institutional Stock Ownership On Stock Returns And Performance: A Financial Market Perspective". Journal of Business \& Economics Research, 3:3, 65-70.

Oxfam America (2020) "Pandemic Profits Exposed". Oxfam Media Briefing, July 22, 2020, https://assets. oxfamamerica.org/media/documents/Pandemic_ Profiteers_Exposed.pdf Viitattu 12.1.2021.

Oxfam International (2021) "The Inequality Virus: Bringing together a world torn apart by coronavirus through a fair, just and sustainable economy". Oxfam briefing paper, January 2021.

Oxfam International (2020) "Power, Profits and the Pandemic: From corporate extraction for the few to an economy that works for all". Oxfam briefing paper, September 2020.

Perälä, Annu (2020) "Nuoret tarvitsevat rahaa menestyäkseen". Eduskuntatutkimuksen keskus. https://blogit.utu.fi/ekeskus/author/anemper/Viitattu 14.1.2021.

Petry, Johannes, Fichtner, Jan \& Heemskerk, Eelke (2020) "It's the index, stupid! Our New Not-So-Neutral Financial Market Arbiters". Notes on the Crises. Substack. https://nathantankus.substack.com/p/its-theindex-stupid-our-new-not Viitattu 29.4.2021.

Reuters (2020) "ECB's Lagarde shifts burden to governments to aid recovery". https://www.reuters. com/article/us-ecb-policy-lagarde/ecbs-lagardeshifts-burden-to-governments-to-aid-recoveryidUSKBN2640BW Viitattu 2021.

Valtiovarainministeriö (2020) "Taloudellinen katsaus. Syksy 2020. Talousnäkymät”. https://julkaisut. valtioneuvosto.fi/bitstream/handle/10024/162468/ VM_2020_70.pdf?sequence=1\&isAllowed=y Viitattu 14.1.2021.

World Bank Group (2020) "Poverty and Shared Prosperity 2020: Reversals of Fortune". https:// openknowledge.worldbank.org/bitstream/ handle/10986/34496/9781464816024.pdf Viitattu 12.1.2021. 